\title{
Contemporary Humanism: Sartre's Existentialist Humanism and Heideggerean Humanism
}

\author{
Ufuk Özen \\ Uludağ University, Faculty of Education, \\ English Language Teaching Department, Görükle Campus, BURSA, TURKEY \\ E-mail: ufukozen@uludag.edu.tr
}

\section{Doi:10.5901/mjss.2013.v4n6p665}

\section{Abstract}

The present study investigates the concept of humanism in terms of the two forms of contemporary humanism, namely Sartre's existentialist humanism and Heideggerean humanism. The aim is to explore the concept in detail and to present the views of Sartre and Heidegger on humanism and to shed a light on the discrepancy of the two views and disprove the arguments of some of the critics who claimed their similarity. Firstly, the concept is explained in terms of different classifications according to the historical era they became prominent and the philosophers or philosophical movements the concept was associated with. Then Sartre's existential humanism is discussed in relation with his "being-for-itself" and idea of human freedom. Sartre's view of humanism is followed by Heideggereanhumanism which isstudied in association with Heidegger's concepts of Dasein and Being. The investigation ends with the emphasis of the difference between Sartre's and Heidegger's views of humanism.

\section{Introduction}

Humanism doesn't have a pure or non-normative definition. Humanism is a concept in shadow like many other philosophical ones and is in a mass of definitions such that if all are accepted as true, there will be noone left as nonhumanist. Humanism is classified in historical perspective as classical humanism, Renaissance humanism or humanism in Enlightenment. On the other hand humanism is possibly classified as Marxist humanism or Heideggerian humanism in terms of the philosopher or philosophical movement.

In the history of philosophy there are some philosophers who claim that there cannot be cohesion between philosophy and humanism while some others argued that philosophy may harmonize with some forms of humanism. Martin Heidegger in his Letters on Humanismtries to make a connection between philosophy and humanism and insisted on his theory's having a humanistic structure. Likewise Jean-Paul Sartre in his Humanism is Existentialism has put forward his views on the concept humanism in a way different from Heidegger. The present paper aims to focus on the concept of humanism and compare and contrast humanism in Heidegger and Sartre, the two forms of contemporary humanism and to enlighten that the ideas of the two philosophers on the concept of humanism are contrasting.

\section{The Concept of Humanism in the History of Philosophy}

Humanism refers to a series of concepts like being about nature, deterministic characteristics education or virtues of humans. In one of its meaning humanism is a philosophical system consistent with its assertions on ontology, epistemology, anthropology, education, aesthetics and politics. In another view humanism is thought of as being the totality of a series of question on nature and human nature. From the $14^{\text {th }} \mathrm{C}$. to $19^{\text {th }} \mathrm{C}$. humanism has been used with five different meanings. First, it has been used as a focus on the classical works of grammar, rhetoric, history, poetry and ethics. Secondly, humanism is used to refer to interests of human beings and the things they portray as central. The third meaning is to approach reason and autonomy as basic sides of human existence. The forth meaning is the use of reason, skepticism and scientific method in searching for reality and configuration of human community. The fifth meaning is the assertion that ethics and the essentials of society can be grasped in autonomy and moral equality. Till $19^{\text {th }}$ century, in addition to these five definitions humanism has been described as human uniqueness, humanistic beliefs centered on scientific method and reason by existentialism, Marxism and pragmatism. (Luik, 1998, 3672) 
Still there is a significant but unclarified relation between philosophy and literature. European humanism hasn't been explored in a theory or text but rather has been described slowly within a very long period of time. Interest in humanism can be extended to Roman tradition. Cicero and Varro made a distinction between humanism with a general meaning of love for humankind and humanism based on Greek word paideia meaning education. Similarly Benda made a classification for humanism: On one hand, humanism is the desire to understand and know humans, the meaning enlivened in the ideas of Kant, Goethe and other followers of Enlightenment. On the other hand with its more general meaning humanism is associated with the discovery of human idea in the Renaissance period. As for different researchers contented humanism in different ways, it is very hard to define the concept. For instance Höffding's humanism is a tendency towards life that regards human as the subject of his observation and the initiator of his action. All these discussions may lead us to three types of humanism. The rebirth of classical writings with a claim to focus on human and social markedness of philosophy signifies an attempt to develop social skills. Hegel's friend, Friedrich Immanuel Niethammer stressed that neo-humanism aims to understand the development of human skills by examining ancient world. If humanism is accepted as an investigation of human being, it addresses the problems of freedom, naturalism, historical view, religion and science. (Rockmore, 2003, 60, 61)

(Luik, 1998, 3673)

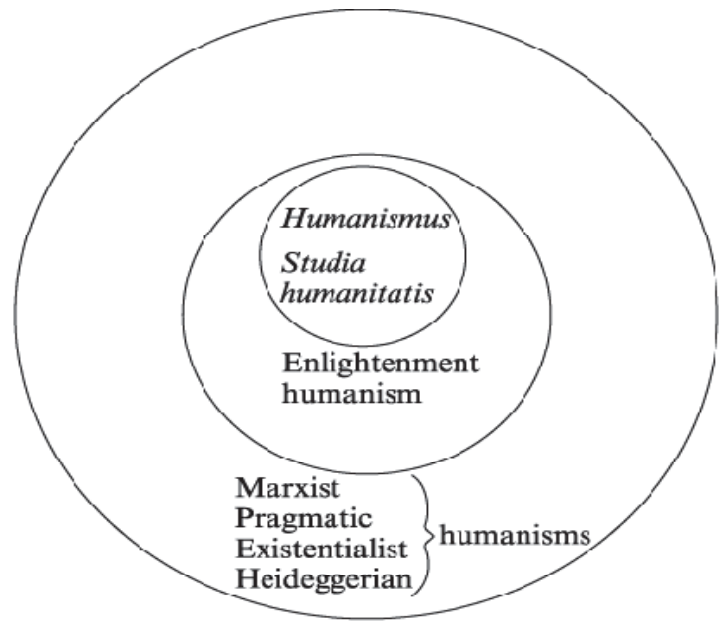

Figure 1

Figure 1 may display a perspective of humanism. The middle circle Humanismus, StudiaHumanitatisis used to refer to antiquity which was later reborn as Italian Renaissance. The second circle in the middle is Enlightenment humanism is used to mean "secular" and "scientific". Enlightenment humanism has often been associated with $17^{\text {th }}$ and 18 century philosophers and man of letters like Voltaire, Rousseau, Locke or Hume and focuses on shaping of human life and society by means of reason rather than the discovery of God's will. Besides it power for criticism and skepticism reason has an objective nature. The outmost circle includes four contemporary humanism types. The one of these forms closest to Enlightenment is the pragmatic humanism reclaimed by Charles Pierce, William James, John Dewey and F.C.S. Schiller. Pragmatic humanism is connected to Enlightenment through primacy of humans, validity of scientific method and its incoherency with religious beliefs. Existentialist humanism is close to Pragmatic humanism with regard to their rejection of a universal human essence and has been associated with Jean Paul Sartre's Existentialism is a Humanism. Marxist humanism, like Enlightenment humanism has rejected belief in God and instrumental rationalism but also didn't accept theessential description of human nature. The last of these contemporary humanism forms is Heideggerian humanism and was revealed in his famous Letter on Humanism.(Luik, 1998, 3673-3674). The present study will follow with the discussion of two forms of contemporary humanism, namely Sartre's and Heidegger's view of humanism.

\section{Sartre's Existentialist Humanism and the Concept of Human Freedom}

When philosophy in France is considered the increasing interest in Husserl, Heidegger and Hegel is a result of Sartre's 
effects on philosophical circle. In terms of French philosophy, Sartre triggered the increase in interest in Hegel, a tendency towards the ideas of Husserl and reading of Heidegger with a particularly misinterpretation. The publication of Sartre's "Being and Nothingness" has directed the attention to Husserl, Hegel and especially Heidegger. As a result of his own concerns, Sartre misinterpreted Heidegger. Heidegger related his own stance to that of pre-Socratics' unlike his students who commented that Heidegger was affected by the texts of Aristotle and Neo-Kantians. (Rockmore, 2003, 76, 77)

His main claim that "existence precedes essence" points his belief that there is nothing objective or permanent about human nature. Right from the beginning, Sartre's thinking is shaped by the problem of humanism. He has studied human as a subject and human freedom and the main philosophical theme in Sartre's philosophy has always been the being..He has also grounded his theory on philosophical anthropology. Sartre's position in his early existentialist period supposes the blending of Descartes and Heidegger, the freedom philosophers in two opposite poles. (Rockmore, 2003, 78) Sartre tried to explore human being on the basis of freedom and in his Being and Nothingness he described human conscious as being independent of its surroundings and human being as having a freedom that condemns him to make a choice. According to Sartre humans are completely free.

Human freedom precedes essence in man and makes it possible; the essence of the human being is suspended in his freedom. What we call freedom is impossible to distinguish from the being of "human reality." Man doesn't exist first in order to be free subsequently; there is no difference between the being of man and his being-free.... Here we are dealing with freedom in connection with the problem of nothingness and only to the extent that it conditions the appearance of nothingness. (Being and Nothingness, Part 1, Chapter 1, Article 5)

In his view of human freedom Sartre united Descartes and anti-Cartesian Heidegger. In fact Sartre's idea of freedom can't be related to Heidegger's. According to Heidegger, freedom is a conservative concept because its authentic meaning signifies the repetition of past in the future and adherence to tradition rather than detachment. But Sartre doesn't view freedom from a traditional starting point and sees freedom as the man's free choice of himself and other selves. He mentions that freedom also brings the responsibility to make a choice and authentic being accepts this responsibility. In other respects, it is a mistake to regard Sartre's theory as a slightly different form of Heidegger's and to do so will be a misinterpretation of Heidegger. The differences between Sartre's and Heidegger's lie in one of Sartre's lectures Existentialism and Humanism where Sartre pointed Heidegger as the source material of his existentialism. Sartre points that the similarity between his and Heidegger's views is their focus on human existence but that they comment on the subject in different ways. Heidegger focuses on human being with regards to the problem of Being. But Sartre's emphasis is on choice and the fact that choices are important in all people's lives and all people have responsibility for the whole world. (Rockmore, 2003, 80)

Sartre maintains that His readers will be astonished by the title Existentialism and Humanism. "... existentialism, in our sense of the word, is a doctrine that does render human life possible; a doctrine, also, which affirms that every truth and every action imply both an environment and a human subjectivity. $(1966,24)$ According to Sartre's existentialist humanism, human nature is nothing more than the choices one makes in acting and performing. There can't be a paradigm to measure human actions. Sartre agrees with pragmatic humanists in their view of human essence, while he shares the same idea with Enlightenment humanism, the idea that human beings are autonomous. Although existentialists like Sartre accept the naturalistic descriptions of human behavior, they asserted that individual or collective human behavior should be explained in terms of freedom and being of its own reason. (Luik, 1998, 3674) Human freedom is a burden for humans to stand to. It is for the fact that one carries this horrible responsibility, he also finds himself in a deep anxiety. Only I can make my own choices and I'm responsible for all my choices to all humankind.

What do we mean that man first of all exists, encounters himself, surges up in the world- and defines himself afterwards. If man as the existentialist sees him is not definable, it is because to begin with he is nothing. He will not be anything until later, and then he will be what he makes of himself.... Man is nothing else but what he makes of himself. ... Man is, indeed, a project which possesses a subjective life. ... In fashioning myself I fashion man. ... For if indeed existence precedes essence, one will never be able to explain one's action by reference to a given and specific human nature; in other words, there is no determinism.(Existentialism and Humanism, 1966, 28 - 34).

In Existentialism and Humanism Sartre gives an example from his own life. During the Second World War one of his students confronted him with a dilemma: In 1940 his brother was killed by Nazis and young man was passionate to revenge for his brother's death and struggle against Nazism. On the other hand his mother was sick unto death because of grief. She was alone and in need of his help. If he had struggled against Nazism he had to leave his mother alone and if he hadn't left his mother, he couldn't revenge for his brother's death. Sartre's advice to his student was "you are free, make your choice". $(1966,35)$ Sartre can't choose for him. To ask for advice is to make a choice but also to choose to 
hear the advice that he desires. In this example Sartre turns the table against the determinist. This is to confront with the real and concrete freedom. Determinism is a scientific abstraction. Even if determinism is true, it can never help the young man to solve his dilemma. Nothing can free us from this burden of responsibility. For Sartre "we are condemned to be free". We have neither chosen to be free nor to exist. In Heidegger's terminology "we are thrown to this world". We don't have a predetermined essence. First we exist and then we shoulder to create ourselves which is a lifelong process and therefore we generate our essence by means of our choices. We are nothing more than what we do. The only restriction on our freedom is that we are not free to avoid making choices. (Priest, 2001, 15-17).

\section{Heideggerian Humanism and the Concept of Dasein}

Although humanism is not a universal tendency, it is considered as the center of enlightenment. Philosophy was apt to an emphasis on an anthropologic approach during enlightenment. Heidegger's humanism shouldn't be taken with a standard meaning of humanism. He rejected the idea of human development and perfectionism and the metaphysical conceptualization of humanism. His view of humanism is shaped by his focus on the concept of Being and thus he didn't break the connection between humanism and philosophy.

It is possible to talk about five factors affecting Heidegger's humanist viewpoint. First factor is the economic breakdown affecting social and political structure worldwide, especially including Europe and France. These difficult economic conditions have directed the attention to certain existential factors related to Heidegger's existentialism. The second factor is a philosophical interest towards traditional French Roman Catholicism, Thomism and various forms of spiritualism. Heidegger's political conservatism has been supported by the ones who rejected liberal philosophy and politics. Thirdly, philosophers in favor of long lasting French Socialist Tradition were interested in the fully development of individual people. French socialism has taken various forms including French Communist Party. Both in Germany and France there appeared a direction towards conservative philosophical views caused as a result of resistance against Bolshevism. The forth factoris a rebirth of interest in Hegel's ideas. The fifth reason is misinterpretations of Hegel's texts in the sense of anthropology. (Rockmore, 2003, 71) For isntance Heidegger explicitly differentiated the study of Dasein from all other human sciences.

In distinguishing the existential analytic from anthropology, psychology and biology, we shall confine ourselves to what is in principle the ontological question. Our distinctions will necessarily be inadequate from the standpoint of 'scientific theory' simply because the scientific structure of the above-mentioned disciplines (not, indeed, the 'scientific attitude of those who work to advance them) is today thoroughly questionable and needs to be attacked in new ways which must have their source in ontological problematics. (Being and Time, Part 1, Division 1, Paragraph 10)

In Letter on Humanism Heidegger critically analyzed Marxist humanism and Sartre's humanism. The main thesis of Heidegger is as follows: The metaphysical humanism, in Heidegger's terms, including the traditional humanism and Enlightenment humanism was wrong in placing human essence in human rationality and overlooked that the resource of human essence lies in existence and in man's primary relation with Being. According to Heidegger traditional humanism erroneously investigated humanism within a metaphysical structure. In this respect Heidegger's humanism rejected metaphysical humanism and centered reason and thinking in studies of human and Being.

Thinking doesn't overcome metaphysics by climbing still higher, surmounting it, transcending it somehow or other; thinking overcomes metaphysics by climbing back down into the nearness of the nearest. The descent, particularly where human beings have strayed into subjectivity, is more arduous and more dangerous than the ascent. The descent leads to the poverty of the ek-sistence of homo humanus. In ek-sistence the region of homo animalis, of metaphysics is abandoned. The dominance of that region is the mediate and deeply rooted basis for the blindness and arbitrariness of what is called "biologism," but also of what is known under the heading "pragmatism." To think the truth of being at the same time means to think the humanity of homo humanus. What counts is humanitas in the service of the truth of being, but without humanism in the metaphysical sense. (Letter on Humanism, 1977, 268).

Heidegger's Letter on Humanism is in a sense a reply to Sartre's existentialist humanism which he explained in Existentialism is Humanism.

But if one understands humanism in general as a concern that the human being become free for his humanity and find his worth in it, then humanism differs according to one's conception of the "freedom" and "nature" of the human being. So too are there various paths toward the realization of such conceptions. The humanism of Marx doesn't need to return to antiquity any more than the humanism that Sartre conceives existentialism to be. In this broad sense Christianity too is a humanism in that according to its teaching everything depends on human salvation; the history of the human being appears in the context of the history of redemption. However different these forms of humanism may be in 
purpose and in principle, in the mode and means of their respective realizations, and in the form of their teaching, they nonetheless all agree on this, that the humanitas of homo humanus is determined with regard to an already established interpretation of nature, history, world and the ground of the world, that is, of beings as a whole.(Letter on Humanism, 1977, 245).

Heidegger's rejection of Sartre's view of humanism displays two important points. Firstly, although Heidegger starts with Sartre's traditional concept of human being, he argued that he will revise the concept without questioning basic but inadequate terms. Secondly, Heidegger opposes the concept of value proposed by Sartre and asserts that virtues are brought to the world by way of humans. Heidegger mentions that to attribute value to something is a kind of subjectification. Heidegger insists that Sartre made a mistake when he didn't return to the starting point before making distinctions between fact and value, theoretical and practical. But Heidegger points that right at the start of his study he made a distinction between Being and being, which was an important philosophical stance. According to Heidegger, Sartre's mistake was not to realize the concept of Dasein as a pioneer in the study of Being. Although Sartre's concept of for-itself seems to be similar to Heidegger's Dasein, in fact Dasein is not a concept concerning all people, but having an ontological function given by Being to humans and maintained by humans. While Sartre's concept of for-itself is an absolute and ultimate reality, the concept of Dasein takes its meaning from the reality of Being, which is a more basic and further thought. Thus, Heideggerargued that the basic principles put forward in Being and Nothingness and Time and Being are in no way similar to each other. (Gardner, 2009, 216)

Çüçen asserts that the place where the reality of Being is revealed is the exposition of ontological structure through the ontic one. The exposition of ontological one through the ontic one is only possible through the being called Dasein because Dasein is the only being that can ask the question of the meaning of Being and can expose its ontological structure through its ontic being. With this argument Heidegger sets about the exposition of the existentialist structure of the being called Dasein and thus to uncover the being from an ontological perspective.(Çüçen, 2003, 133134)

Heidegger placed the problem of Being at the center of his philosophical investigation.

Heidegger distinguishes this investigation from psychology, anthropology and biology and argues that the existential analysis of Dasein is prior to them. Heidegger didn't use the term "Dasein" to mean human. For Heidegger, Dasein is a being that can question its being in what is not Dasein and in the world. In other words Dasein is an ontological reality in which the analysis of Being and its structure are presented.(Çüçen, 2003, 134).

Dasein is thrown into this world and finds itself in the world as a "Being-in as such". The fact that it was thrown into the world is a predestination determined for it but there is no essence predetermined for Dasein. Heidegger expresses that his philosophy is not an existentialist one. Çüçen explains the difference between Heidegger and existentialists like this: "One investigates the conditions of existence grounded in Being, the other investigates the basis for human existence." $(2003,136)$

According to Heidegger, when Sartre argued that "existence precedes essence" he used the expressions of existentia andessentia, similar to Plato's use of the expression "essentia precedes existentia" with a metaphysical meaning. Heidegger insisted that Sartre reversed the expression, but the reversion of a metaphysical expression is another metaphysical one. (Letter on Humanism, 1977, 250) In this way, the apriori and direct understanding of being is covered under metaphysics. Yet, Heidegger's aim is to develop an ontologically grounded theory of being by reinterpreting the understanding attached to Cartesian tradition.

\section{Conclusion}

The present study investigated two contemporary forms of humanism, namely Sartre's existentialist humanism and Heideggerean humanism and displayed how different the two forms of humanism are on the contrary to many comments made in literature. Firstly in the study it has been pointed that there is no single way of defining humanism and the concept of humanism has been classified in various ways either according to a historical processing or the philosophers or the philosophical movements the concept has been associated with. After a brief introduction of the different meaning the concept was associated with, the study's focus was on two forms of contemporary humanism, the form which was associated with Sartre and the one with Heidegger. It has been pointed out that some critics claimed that the two philosophers' ideas on humanism are similar, but the study displayed an opposite case. In order to demonstrate the contrast between the ideas of Sartre and Heidegger on humanism, first Sartre's existentialist humanism was discussed through his important works Being and Nothingness and Existentialism and Humanism. In Being and Nothingness the concept of for-itself was explored a Sartre's basic view on human being. Then in Existentialism and Humanism, how 
Sartre related existentialism and humanism was discussed. The other contemporary form of humanism is Heideggerean humanism, which is closely and directly related to his concept of Dasein, the concept which is fully explore in Being and Time. How the two forms contrast is discussed in Heidegger's Letter on Humanism which is Heidegger's reply to Sartre.

\section{References}

Çüçen, A.Kadir. (2003) Heidegger'deVarlıkveZaman.AsaKitapevi, Bursa.

Gardner, Sebastian. (2009) Sartre's Being and Nothingness: A Reader's Guide. Continuum International Publishing Group, London \& New York.

Heidegger, Martin.(2008) Being and Time.trans. John Macquarrie\& Edward Robinson. Harperperennial- Modern Thought, New York.

Heidegger, Martin.(1977) Letter on Humanism.trans. J.G. Grey \& F.A. Capuzzi. Harper \& Row, New York.

Luik, John C. (1998) "Humanism" Concise Routledge Encyclopedia of Philosophy. Routledge, London \&New York.

Rockmore, Tom. (2003) Heidegger and French Philosophy.Taylor \&FrancisRoutledge, USA \&Canada.

Sartre, Jean- Paul. (1984) Being and Nothingness: A Phenomenological Essay on Ontology. trans. Hazel E. Barnes. Philosophical Library, Inc., New York.

Sartre, Jean- Paul. (1966) Existentialism and Humanism.trans. Philip Mairet. Methuen \& Co Ltd., London.

Priest, Stephen. (2001) Jean-Paul Sartre: Basic Writings.Routledge:London. 